\title{
SHADE AND AIRFLOW RESTRICTION EFFECTS ON CREEPING BENTGRASS GOLF GREENS
}

\author{
By \\ KYUNGJOON KOH \\ Bachelor of Science \\ North Carolina State University \\ Raleigh, North Carolina \\ 1998
}

Submitted to the Faculty of the

Graduate College of the

Oklahoma State University

in partial fulfillment of the requirements for

the Degree of

MASTER OF SCIENCE

December, 2001 


\section{SHADE AND AIRFLOW RESTRICTION EFFECTS ON CREEPING BENTGRASS GOLF GREENS}

Thesis Approved:
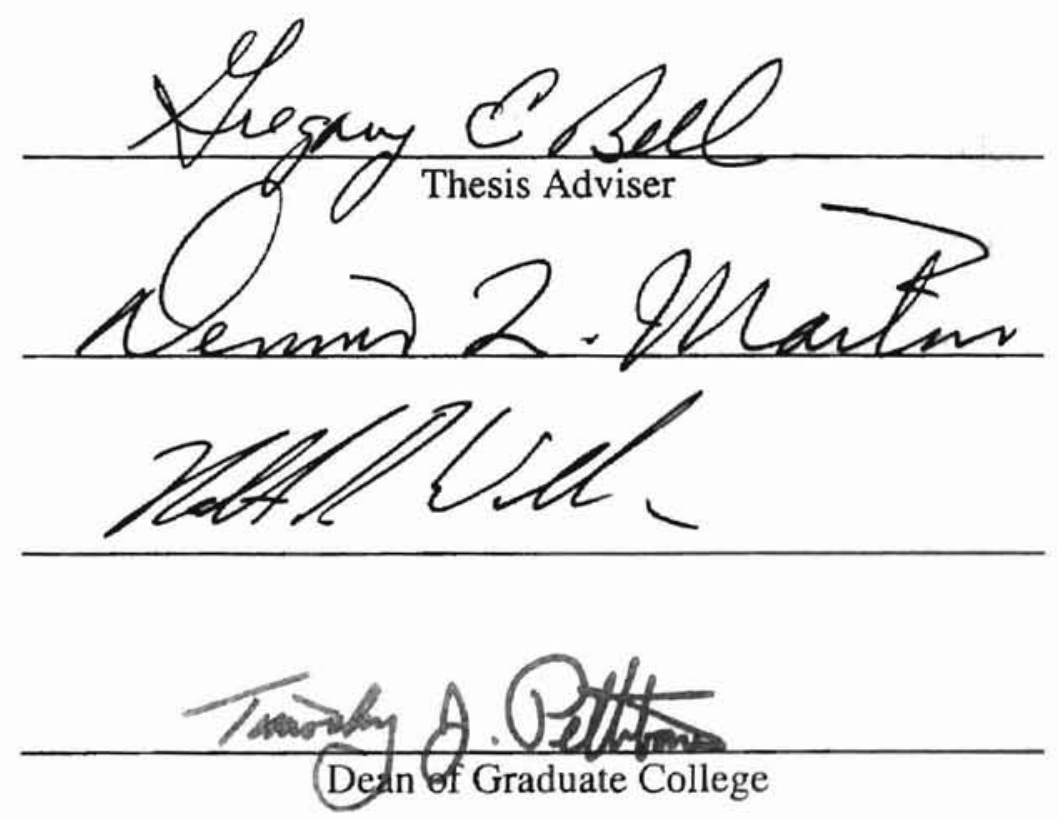


\section{ACKNOWLEDGEMENT}

I wish to express my sincere appreciation to my major professor, Dr. Greg E. Bell, for his guidance, patience, encouragement, and advice throughout this research. I would like to thank Dr. Dennis L. Martin, and Dr. Nathan W. Walker for serving on my graduate, and for their help and advice.

I additionally thank Dr. Niels Maness, for his guidance, knowledge and advice and Donna Chrz, for her assistance in the laboratory. Thanks are extended to Dr. Michael Smith for his advice and assistance with my data analysis. Additional thanks go to Chris Stiegler, Justin Moss, and Starla Weise for their assistance and friendship throughout my graduate years. Finally, I would thank Keith Reed, superintendent of the OSU turfgrass research center, and his staffs for their patience, work, and care of my research sites.

I am deeply grateful for my wife, Soyoun Park, for her love, care, and support

from New York during my graduate years. She has meant more than anything to me throughout this journey. Special thanks go to my parents Heungchul Koh, and Sookja Lee, for their endless love, devotion, and encouragement from Korea. 


\section{TABLE OF CONTENTS}

Chapter Page

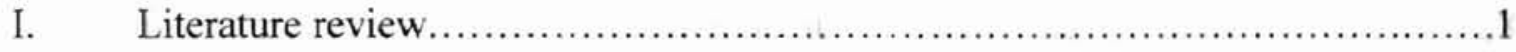

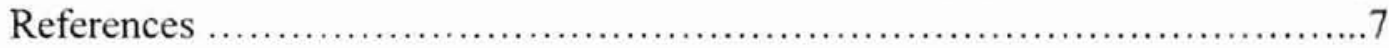

II. SHADE AND AIRFLOW RESTRICTION EFFECTS ON CREEPING BENTGRASS GOLF GREENS

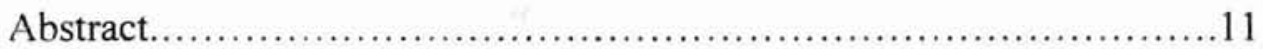

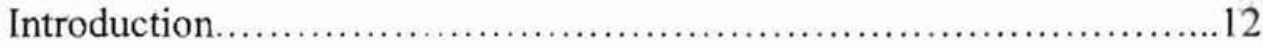

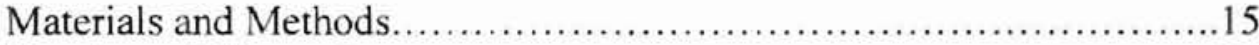

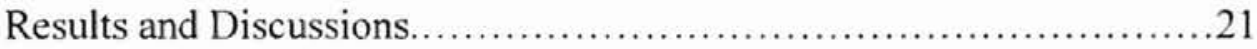

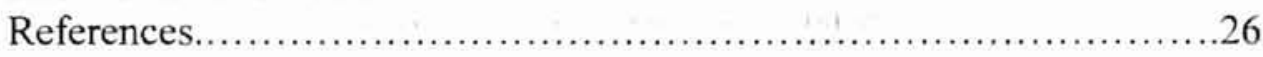




\section{LIST OF TABLES}

Table

Page

1a. Turf canopy, soil, and air temperatures $\dagger$ for creeping bentgrass (Agrostis palustris Huds.) cultivar, 'SR1020'. Means are based on three subsamples from three replications of each treatment..................................... 28

1b. Turf canopy, soil, and air temperatures $\dagger$ for creeping bentgrass (Agrostis palustris Huds.) cultivar, 'L93'. Means are based on three subsamples from three replications of each treatment

2a. Turf color ratings $\dagger$ (percentage of potential density) for creeping bentgrass (Agrostis palustrisHuds.) cultivar, 'SR1020'. Means are based on three subsamples from three replications of each treatment.

2b. Turf color ratings $\dagger$ (percentage of potential density) for creeping bentgrass (Agrostis palustris Huds.) cultivar, 'L93' . Means are based on three subsamples from three replications of each treatment.

3a. Turf density ratings $\uparrow$ for creeping bentgrass (Agrostis palustris Huds.) cultivar, 'SR1020'. Means are based on three subsamples from three replications of each treatment.

3b. Turf density ratings $\dagger$ for creeping bentgrass (Agrostis palustris Huds.) cultivar, 'L93'. Means are based on three subsamples from three replications of each treatment.

4a. Dollar spot (Sclerotinia homoeocarpa F. T. Bennett) and brown patch (Rhizoctonia solani Kuhn.) assessments † for creeping bentgrass (Agrostis palustris Huds.) cultivar, 'SR1020'. Means are based on three subsamples from three replications of each treatment

4b. Dollar spot (Sclerotinia homoeocarpa F. T. Bennett) and brown patch (Rhizoctonia solani Kuhn.) assessments $\uparrow$ for creeping bentgrass (Agrostis palustris Huds.) cultivar, 'L93'. Means are based on three subsamples from three replications of each treatment

5. Relative soil moisture content $\dagger$ for creeping bentgrass (Agrostis palustris Huds.) cultivars, 'SR1020' and 'L93'. Means are based on three subsamples from three replications of each treatment. 
6. Root mass $\dagger$ for creeping bentgrass (Agrostis palustris Huds.) cultivars, 'SR1020' and 'L93'. Means are based on three subsamples from three replications of each treatment

7. Total nonstructural carbohydrates (TNC) $\uparrow$ for creeping bentgrass (Agrostis palustris Huds.) cultivars, 'SR1020' and 'L93'. Means are based on three subsamples from three replications of each treatment in 2000 .... 
l.iterature Revien

CHAPTER I

LITERATURE REVIEW 


\section{Literature Review}

Creeping bentgrass (Agrostis palustris Huds) ) is the most commonly used coolseason grass for golf course greens because it tolerates low mowing heights, provides high functional quality, and maintains a desirable appearance (Turgeon, 1991). Creeping bentgrass has moderate shade tolerance (Dudeck and Peacock, 1992); however, reduced photosynthetic radiation combined with close mowing height, intense irrigation, traffic, and wear increases the severity of certain diseases caused by pathogens such as Rhizoctonia solani Kuhn (brown patch), Sclerotinia homoeocarpa F.T. Bennett (dollar spot), Pythium spp. (Pythium blight), and Fusarium spp. (Fusarium blight) (Beard 1965; Vargas and Beard, 1981; Winstead and Ward, 1974).

Up to 25 percent of turf in the U.S. is grown in shade. Shaded sites involve a complex of environmental factors (Beard, 1973). Shade combined with airflow restriction caused by trees, shrubs, and other barriers creates detrimental microenvironments for turf health and growth. These microenvironments are more detrimental for turf growth when barriers occur on the east and south, which alters the spectral composition of light which causes undesirable plant characteristics, prolongs leaf wetness, and increases relative humidity which may increase disease severity or turf injury combined with other environmental stress.

Solar radiance available for plant growth occurs in a spectral band from 400 to $700 \mathrm{~nm}$ wavelengths and is called photosynthetically active radiation (PAR).

Wavelengths from 400 to $500 \mathrm{~nm}$, called blue light, and wavelengths from 600 to $700 \mathrm{~nm}$ called red light, are required for photosynthesis, photomorphogenesis, and chlorophyll 
synthesis (Blackwell, 1966). Green light, PAR from 500 to $600 \mathrm{~nm}$, has limited value for plant growth and development. Far-red light (wavelengths from 700 to $800 \mathrm{~nm}$ ) is inactive for photosynthesis, but strongly influences photomophogenesis (McMahon et al., 1991; Casal and Sanchez, 1994).

Chlorophyll $\mathrm{a}$ and $\mathrm{b}$ are the main photosynthetic pigments in plants. The chlorophylls are supported by accessory pigments called carotenoids that include hydrocarbon carotenes and xanthophylls. Chlorophyll a absorbs light maximally at wavelengths near $410 \mathrm{~nm}, 430 \mathrm{~nm}$, and $660 \mathrm{~nm}$ while chlorophyll b has peak absorbance at 430nm, 455nm, and 640nm (French, 1961). Carotenoids absorb light most actively at or near 450nm (Harding, and Shropshire, 1980). Phytochrome, meaning 'plant color', is a photomorphogenic pigment that exists in two forms called red light absorbing phytochrome (Pr) and far-red light absorbing phytochrome (Pfr). The absorption maximum of Pr is near 660nm while that of Pfr is near $730 \mathrm{~nm}$ (Grant, 1997; Hart, 1988). A third type of photo-acceptor called cryptochrome, meaning 'hidden color' responds to blue light. The chemical nature of this blue-light photoreceptor is not well understood, however, it is believed that there are blue light and ultra violet absorbing pigments that effect plant growth and development (Bell et al., 2000; Hart, 1988).

In cool-season grasses, photosynthetic productivity increases with increasing PAR from 116 to $233 \mathrm{~W} \mathrm{~m}^{-2}$ (Dudeck and Peacock, 1992). Gaussoin (1988) reported that the light saturation point for creeping bentgrass $\left(\sim 1000 \mu \mathrm{mol} \mathrm{m}^{-2} \mathrm{~s}^{-1}\right)$ was not reached in shade and light saturation for Kentucky bluegrass $\left(\sim 500-600 \mu \mathrm{mol} \mathrm{m}^{-2} \mathrm{~s}^{-1}\right)$ was reached for only a short period of time near solar noon in deciduous shade. Bell and Danneberger (1999) reported that perpetual artificial shade averaging 42 percent of the photosynthetic 
photon flux available in full sun caused significantly lower turf density and root mass than turf grown in full sun. Creeping bentgrass maintained color, density, and tissue mass when shaded at 31 percent of full sun for 40 percent of each day. It was concluded that the duration of shade is most destructive to turfgrass growth and development rather than the density of shade or the temporal period of shade.

Reduced light intensity alters several physiological and morphological characteristics of plants. Even though heat stress is reduced during the summer months, turf grown under low levels of solar radiant energy was more succulent and disease was more severe due to prolonged dews and increased relative humidity (Beard, 1965). Turf grown in shade was more susceptible to injury caused by traffic and/or environmental stress (Cockerham et al., 1994; Dudeck and Peacock, 1992). Because of a decrease in photosynthesis caused by limited PAR in shade, available carbohydrates as well as total nonstructural carbohydrates (TNC) decreased in 'Coastal' bermudagrass (Cynodon dactylon (L.) Pers.) (Burton et al., 1959). Low radiant flux increased stem elongation, lengthen leaf sheaths, and reduce tillering for 'Diamond' zoysiagrass (Zoysia matrella (L.) Merr.) (Qian and Engelke, 1999). Wikinson and Beard (1974) demonstrated that leaf length increased when PAR decreased below $83 \mathrm{~W} \mathrm{~m}^{-2}$. Leaf length was reduced at PAR levels below $83 \mathrm{~W} \mathrm{~m}^{-2}$ in 'Merion' Kentucky bluegrass (Poa pratensis L.) and 'Pennlawn' red fescue (Festuca rubra L.) (Wilkinson, 1975). Plant growth was more vertical in shade caused by an inactivation of phytochrome influenced by far-red irradiance which results in an increase in gibberellic acid (Rood et al., 1986). A turfgrass grown in shade is lighter green in color and less dense (Bell and Danneberger, 1999; Juska, 1960; Wilkinson and Beard, 1975). However, turf in shade can be darker green 
than that in full sun (Dudeck and Peacock, 1992; Winstead and Ward, 1974). These conflicting reports may be caused by differences in shade density, duration or by differences in light quality (Bell and Danneberger, 1999; Bell et al., 2000).

Air movement influences turf growth and development by cooling, increasing transpiration, enhancing carbon dioxide flux, removing water vapor, and redistributing heat (Beard, 1973). Poor air circulation around golf greens caused by dense trees and shrubs or other factors increases soil moisture content and causes a reduction in plant transpiration. Turbulent transfer generated by air movement tends to increase the carbon dioxide concentration adjacent to plant leaves to the normal atmospheric level of 300 ppm (Champman et al, 1954; Monteith et al, 1964; Wiant, 1964). The effects of air movement on transpiration are complex because increasing wind speed decreases boundary layer resistance, but also cools leaves, decreasing the vapor pressure gradient from leaf to air (Kramer and Boyer, 1995). Air movement of $1.79 \mathrm{~m} \mathrm{~s}^{-1}$ decreased turf canopy temperature a maximum of $7.2^{\circ} \mathrm{C}$ compared to no air movement, but the relative humidity at $7.6 \mathrm{~cm}$ above the turf surface was not affected by air movement (Duff and Beard, 1966). Grace and Russell (1977) reported that tall fescue (Festuca arundinacea Schreb.) exposed to an average wind speed of $0.5-1.0 \mathrm{~m} \mathrm{~s}^{-1}$ resulted in more adaxial macro and prickle hairs, shorter, more narrow leaves, stiffer leaf segments, more stomata per unit area, a decrease in specific leaf area, and thicker leaves than tall fescue grown under nearly still air in a glasshouse. Russell and Grace (1978) also found that there were no significant increases in cuticular and stomatal conductance between wind speed $0.3 \mathrm{~m}$ $\mathrm{s}^{-1}$, and wind with an average speed of $1.7 \mathrm{~m} \mathrm{~s}^{-1}$ in perennial ryegrass (Lolium perenne L.). Kitano and Eguchi (1992) reported that a sudden increase in wind speed caused an 
increased in absorption, transpiration, and stomatal conductance of cucumber plants in bright light, with decreased responses in low light and no response in darkness. Under restricted air movement, turf canopy temperature was greater than air temperature from 11 A.M. to 5 P.M. while canopy temperature remained cooler than air temperature during the daytime when airflow was $1.79 \mathrm{~m} \mathrm{~s}^{-1}$ (Duff and Beard, 1966). These researchers also found that soil temperature below $5 \mathrm{~cm}$ from the turf surface was higher when air movement was restricted than in air movement at $1.79 \mathrm{~m} \mathrm{~s}^{-1}$. This high soil temperature caused more detrimental effects than high air temperature on creeping bentgrass quality, photosynthetic rate, and root growth (Xu and Huang, 2000). Brown and Wilson (1905) found that the rate of cooling on leaves was directly proportional to the speed of airflow up to $2.24 \mathrm{~m} \mathrm{~s}^{-1}$. The incident of brown patch (Rhizoctonia solani Kuhn), Pythium blight (Pythium spp.), and leaf spot (Drechslera dictyoides (Drechs.) Shoemaker.) is usually higher when air movement is restricted (Turgeon, 1991). 


\section{References}

Beard, J.B. 1965. Factors in the adaptation of turfgrasses to shade. Agron. J. 57:457459.

Beard, J.B. 1973. Turfgrass: Science and Culture. Prentice Hall, Inc., Englewood Cliffs, NJ. p 181-208 and 313-324.

Bell, G.E., and T.K. Danneberger. 1999. Temporal shade on creeping bentgrass turf. Crop Sci. 39:1142-1146.

Bell, G.E., T.K. Danneberger, and M.J. McMahon. 2000. Spectral irradiance available for turfgrass growth in sun and shade. Crop Sci. 40:189-195.

Blackwell, M.J. 1966. Radiation meteorology in relation to field work. In R. Bainbridge et al. (ed) Light as an Ecological Factor. British Ecological Society. Blackwell Scientific Publ., Oxford, England.

Brown, H.T., and W.E. Wilson. 1905. On the thermal emissivity of a green leaf in still and moving air. Proceedings of the Royal Society of London, Series B. 76(507): 122-137.

Burton, G.W., J.E. Jackson, and F.E. Knox. 1959. The influence of light reduction upon the production, persistence, and chemical composition of Coastal bermudagrass, Cynodon dactylon. Agron. J. 51:537-542.

Casal, J.J., and R.A. Sanchez. 1994. Impaired stem-growth responses to blue-light radiance in light-grown transgenic tobacco seedlings overexpressing Avena phytochrome A. Physiologia Plantarum. 91:268-272.

Champman, H.W., L.S. Gleason, and W.E. Loomis. 1954. The carbon dioxide content of field air. Plant Physiology. 29(6):500-503.

Cockerham, S.T., V.A. Gibault, and M. Borgonovo. 1994. Traffic effects on turfgrasses under restricted light. Calif. Turfgrass Cult. 44 (1, 2):1-3.

Dudeck, A.E., and C.H. Peacock. 1992. Shade and turfgrass culture. In D.V. Waddington et al. (ed). Turfgrass. ASA Monogr. 32. ASA, CSSA, and SSSA, Madison, WI.

Duff, D.T., and J.B. Beard. 1966. Effects of air movement and syringing on the microclimate of bentgrass turf. Agron. J. 58:495-497.

French, C.S. 1961. Light pigments and photosynthesis. In W.E. McElroy and B. Blass (ed). A symposium on Light and Life. John Hopkins Press, Baltimore, MA. 
Gaussoin, R.E. 1988. Species dominance in mixed stands of creeping bentgrass and annual bluegrass. Ph.D. diss. Michigan State Univ., East Lansing.

Grace, J, and G. Russell. 1977. The effect of wind on grasses. III. Influence of continuous drought or wind on anatomy and water relations in Festuca arundinacea Schreb. J. Exp. Bot. 28:268-278.

Grant, R.H. 1997. Partitioning biologically active radiation in plant canopies. Int. J. Biometeorol. 40:26-40.

Harding, R.W., and W. Shropshire, Jr. 1980. Photocontrol of carotenoid biosynthesis. Ann. Rev. Plant Physiol. 31:217-238.

Hart. J.W. 1988. Light and Plant Growth. Unwin Hyman Ltd., London, England.

Juska, F.V. 1960. Shade tolerance of bentgrass. Golf Course Reporter. 31(2):28-30,34.

Kitano and Iguchi. 1992. Dynamics of whole-plant water balance and leaf growth in response to evaporative demand. II. Effect of change in wind velocity. Biotronics 21:5160.

Kramer, P.J, and J.S. Boyer. 1995. Water relations of plants and soils. Academic Press, San Diego, CA. p 212-214 and 270-271.

McMahon, M.J., J.W. Kelly, D.R. Decoteau, R.E. Young, and R.K. Pollock. 1991. Growth of Dendranthema grandiflorum Ramat. Kitamura under various spectral filters. J. Am. Soc. Hort. Sci. 1 16:950-954.

Monteith, J.L, G. Szeicz, and K. Yabuki. 1964. Crop photosynthesis and the flux of carbon dioxide below the canopy. J. Applied Ecology. 1:321-337.

Qian, Y.L., and M.C. Engelke. 1999. Influence of trinexapac-ethyl on 'Diamond' zoysiagrass in a shade environment. Crop Sci.39:202-208.

Rood, S.B., F.D. Beall, and R.P. Pharis. 1986. Photocontrol of gibberellin metabolism in situ in maize. Plant Physiol. 80: 448-453.

Russell, G., and J. Grace. 1978. The effect of wind on grasses. IV. Some influence of drought or wind on Lolium perenne. J. Exp. Bot. 29:245-255.

Turgeon, A.J. 1991. Turfgrass Management. $3^{\text {rd }}$ ed. Prentice Hall, Englewood Cliffs, NJ.

Vargas, J.M., and J.B. Beard. 1981. Shade environment-disease relationships of Kentucky bluegrass cultivars. p. 391-395. In R.W. Sheard (ed.) Proceedings of the Fourth International Turfgrass Research Conference., Guelph, Ontario, Canada. 
Wiant, H.V. 1964. The concentration of carbon dioxide at some forest micro-sites. J. Forestry. 62(11):817-819.

Wilkinson, J.F. 1975. Anatomical responses of 'Merion' Kentucky bluegrass and 'Pennlawn' red fescue at reduced light intensities. Crop Sci. 15:189-194.

Wilkinson, J.F., and J.B. Beard. 1974. Morphological responses of Poa pratensis and Festuca rubra to reduced light intensity. p. 231-240. In E.C. Roberts (ed.). Proceedings of the Second International Turfgrass Research Conference. Am. Soc. of Agron., Madison, WI.

Winstead, C.W., and E.Y. Ward. 1974. Persistence of southern turfgrasses in a shade environment. P. 221-230. In E.C Roberts (ed.). Proceedings of the Second International Turfgrass Research Conference. Am. Soc. of Agron., Madison, WI.

Xu, Q., and B. Huang. 2000. Growth and physiological responses of creeping bentgrass to changes in air and soil temperatures. Crop Sci. 40:1363-1368. 
CHAPTER II

SHADE AND AIRFLOW RESTRICTION EFFECT ON CREEPING BENTGRASS GOLF GREENS 


\begin{abstract}
The amount of turfgrass grown under shaded conditions in the United Stated is as high as $25 \%$ (Beard, 1973). Creeping bentgrass (Agrostis palustris Huds.) golf greens are often shaded by trees and shrubs that restrict airflow during the growing season. Light reduction in shade usually combined with airflow restriction is detrimental for turf growth and development. It is, however, possible to consider shade and airflow restriction independently to diagnose specific effects from each factor. The objective of this study was to evaluate and compare turfgrass response to light reduction and airflow restriction on two different creeping bentgrass cultivars. Artificial structures were designed to provide treatment effects. The structures $(122$ by $122 \mathrm{~cm})$ were assembled from polyvinyl chloride pipe $(3.8 \mathrm{~cm}$ in diameter), and covered with black, woven polyester shade cloth ( $80 \%$ light reduction). Shade cloth was applied to the structures to reduce irradiance and allow airflow or reduce airflow and allow irradiance. Plots were rated monthly for visual color, density, disease assessment, soil moisture, canopy, soil, and air temperature, root mass, and total nonstructural carbohydrate (TNC). Two years results indicated that no significant difference occurred in soil moisture content between
\end{abstract}


treatments. Canopy and soil temperature were significantly lower in shaded plots than in airflow restricted and control plots. The severity of brown patch (Rhizoctonia solani Kuhn) and dollar spot (Sclerotinia homoeocarpa F.T. Bennett) in shade was less than in airflow restricted, and control plots.

\section{Introduction}

Creeping bentgrass (Agrostis palustris Huds.) is the most widely used cool season grass for golf greens even though it declines severely due to intense management and environmental stresses during the summer months. A reduction in solar radiance caused by shade is usually combined with other environmental stresses such as airflow restriction and tree root competition that reduce creeping bentgrass quality in shade. Light reduction alters several physiological and morphological characteristics of plants. Low light results in increased stem elongation, longer leaf sheaths, higher chlorophyll content, and higher leaf succulence (Dudeck and Peacock, 1992). Plant growth is more vertical in shade caused by an inactivation of phytochrome influenced by far-red irradiance resulting in an increase in gibberellic acid (Rood et al., 1986). Low radiant flux can increase stem elongation, lengthen leaf sheaths, and reduce tillering in 'Diamond' zoysiagrass (Zoysia matrella (L.) Merr.) (Qian and Engelke, 1999) even though under certain conditions moderate shade may increase tillering (Inosaka et al., 1977 ) and shoot growth (Eriksen and Whitney, 1981). Because of decreases in photosynthesis rate caused by limited PAR in shade, available carbohydrates as well as 
total nonstructural carbohydrates (TNC) decreased in 'Coastal' bermudagrass (Cynodon dactylon (L.) Pers.) (Burton et al., 1959). Turf under shade is more susceptible to disease caused by pathogens such as as Rhizoctonia solani Kuhn (brown patch), Sclerotinia homoeocarpa F.T. Bennett (dollar spot), Pythium spp. (Pythium blight), and Fusarium spp. (Fusarium blight) due to high soil moisture contents and more succulent leaf tissue (Beard, 1973; Vargas and Beard, 1981).

Recently, Bell and Danneberger (1999) concluded that there was no significant effect on creeping bentgrass quality between morning shade opposed to afternoon shade. The researchers determined that the duration of shade was more detrimental to turfgrass health than either density of shade or the temporal period of shade. In that study researchers reported that perpetual artificial shade averaging 42 percent of the photosynthetic photon flux available in full sun caused significantly lower turf density and root mass compared with turf grown in full sun. Creeping bentgrass maintained color, density, and tissue mass even when shaded at 31 percent of full sun for 40 percent of each day.

Airflow restriction decreases cooling effect by reducing transpiration rate, increasing soil moisture content, and decreasing carbon dioxide flux. Airflow promotes heat transfer by forced convection across the leaf boundary layer, and wind speed affects boundary layer resistance between the leaf surface and the ambient air (Nobel, 1991). Airflow increases transpiration, and contributes to decreases in stomatal and cuticular resistances that promote cooling by redistributing heat (Beard, 1973). However, excessive wind speed reduced grass growth even in the absence of water stress (Russell and Grace, 1978, 1979). Kitano and Eguchi (1992) reported that a sudden increase in 
wind speed caused an increase in water absorption, transpiration, and stomatal conductance of cucumber plants in bright light, with decreased responses in low light and no response in darkness. Air movement of $1.79 \mathrm{~m} \mathrm{~s}^{-1}$ decreased turf canopy temperature a maximum of $7.2^{\circ} \mathrm{C}$ compared with no air movement on creeping bentgrass, but the relative humidity at $7.6 \mathrm{~cm}$ above the turf surface was not affected by air movement at that rate (Duff and Beard, 1966). Tall Fescue (Festuca arundinacea Schreb.) exposed to an average turbulent airflow speed of $0.5-1.0 \mathrm{~m} \mathrm{~s}^{-1}$ had a much higher conductance and lost water at more than twice the rate of controlled tall fescue with optimal conditions for growth (Grace and Russell, 1977).

Bell and Danneberger (1999) concluded that it is possible to separate shade and airflow restriction independently to diagnose specific effects from each factor. Treating the detrimental effects of light and airflow restriction independently may improve the management techniques available to turfgrass managers. The objective of this study was to compare and evaluate turfgrass response to light reduction and airflow restriction on two different creeping bentgrass cultivars. 


\section{Materials and Methods}

\section{Experimental Design}

This study was conducted at the Oklahoma State University Turfgrass Research Center, Stillwater, OK. An 'L-93' creeping bentgrass area (Soil pH $=7.3), 11 \mathrm{~m}$ by $49 \mathrm{~m}$ and a 'SR 1020' creeping bentgrass area (Soil $\mathrm{pH}=7.4$ ), $18 \mathrm{~m}$ by $31 \mathrm{~m}$ were used for the study. Each research site was managed as a golf course green on sandy soil. Both sites were basically mowed six times a week at $4 \mathrm{~mm}$ in height with a walk behind mower. Isobutylidenediurea (21-3-16) was applied at the rate of $24 \mathrm{~kg} \mathrm{~N} \mathrm{ha}^{-1}$ during the spring and fall months (March, April, May, September, and October) and $12 \mathrm{~kg} \mathrm{~N} \mathrm{ha}^{-1}$ during the summer months (June, July, and August). These ranges were aerated and topdressed with pure sand each spring and fall in 2000 and 2001. Chlorothalonil (tretachloroisophthalonitrile) was applied preventatively to the research sites every three weeks to help control brown patch (Rhizoctonia solani Kuhn) and dollar spot (Sclerotinia homoeocarpa F.T. Bennett) disease and chlorpyrifos $[O, O$-diethil $O$-(3,5,6-trichloro-2pyridyl) phosphorothioate] was applied curatively to control black cutworm (Agrotis ipsilon Hufnagel) and sod webworm (multiple genera) populations. A wheel chair $\mathrm{CO}_{2}-$ powered sprayer was used for fungicide and insecticide applications. Plots were carefully spaced on each area to eliminate light and airflow interference with each other. Each treatment was replicated three times at each site.

Artificial structures were designed and constructed to provide either airflow restriction or light reduction treatment effects. The structures were assembled from polyvinyl chloride pipe (PVC) with $3.8 \mathrm{~cm}$ inside diameter, and covered with black, woven, polyester shade cloth (Chicopee, Gainesville, GA) rated for $80 \%$ light reduction. 
Structures were constructed to allow rainfall and irrigation to reach the plots evenly and were tested against control plots for that purpose. Each structure was $30 \mathrm{~cm}$ in height, and $122 \mathrm{~cm}$ in width and length. The shade cloth covered only the top of the light reduction structures and the sides were left open to allow air movement across the turf. The sides of the airflow restriction structures were covered with shade cloth to limit air movement but open to sunlight except for very short periods $(\sim 1 \mathrm{~h})$ at the beginning and end of each day. The structures were mounted in PVC pipe sleeves buried into the soil to allow easy removal for mowing, fertilization, and other cultural practices. The structures were placed on the research sites on March 20, 2000 through October 19, 2000, and again on April 20, 2001 through October 19, 2001. Solar irradiance, air speed, canopy, soil, and air temperatures, visible color, density, and disease assessment, root mass, and root carbohydrates were measured monthly to determine treatment effects.

\section{Air Speed and Solar Irradiance.}

Air speed $\left(\mathrm{m} \mathrm{s}^{-1}\right)$ was measured on the same dates as irradiance using a portable multi-directional impeller anemometer (Skywatch, Yverdon, Switzerland). Air speed was measured three times in each plot at $10 \mathrm{~cm}$ above the turf surface monthly. The subsamples from each plot were averaged prior to statistical analysis.

Light energy was measured using a spectroradiometer (Analytical Spectral Devices Inc., Boulder, CO). Irradiance levels for each plot were determined on the $20^{\text {th }}$ or soon after the $20^{\text {th }}$ day of each month under clear skies. Solar irradiance was recorded in irradiant energy $\left(\mathrm{W} \mathrm{m}^{-2} \mathrm{~nm}^{-1}\right)$ and converted to photon flux $\left(\mu \mathrm{mol} \mathrm{m} \mathrm{m}^{-2} \mathrm{~s}^{-1}\right)$ for blue $(400-500 \mathrm{~nm})$, green $(500-600 \mathrm{~nm})$, red $(600-700 \mathrm{~nm})$, and far-red $(700-800 \mathrm{~nm})$ 
wavelengths. Photosynthetic photon flux $(400-700 \mathrm{~nm})$ was used to calculate and compare photosynthetic proportion in each treatment. The formula for conversion of solar energy to photon flux is:

E of a photon $=\mathrm{h} \times \mathrm{c} /$ wavelength

$$
\begin{aligned}
& \mathrm{E}=\text { energy in Joules } \\
& \mathrm{h}=\text { Planck's constant }=6.6255 \times 10^{-34} \text { Joules } \cdot \text { second } \\
& \mathrm{c}=3.0 \times 10^{8} \mathrm{~m} \mathrm{~s}^{-1} \\
& \text { wavelength = wavelength in meters }
\end{aligned}
$$

Therefore:

Energy of a photon $=\left(6.6255 \times 10^{-34} \mathrm{~J} \cdot \mathrm{s}\right)\left(3.0 \times 10^{8} \mathrm{~m} \mathrm{~s}^{-1}\right) /$ wavelength

$$
=1.9877 \times 10^{-25} \mathrm{~J} / \text { wavelength in meters }
$$

The energy in a mole of photons is:

$=\left(1.9877 \times 10^{-25} \mathrm{~J} /\right.$ wavelength in meters $)\left(6.02 \times 10^{23}\right)$

$=0.1197 \mathrm{~J} /$ wavelength mole ${ }^{-1}=119.7 \mathrm{~J} /$ wavelength $\mu$ mole $^{-1}$

To convert energy to photon flux of $450 \mathrm{~nm}$ :

$119.7 \mathrm{~J} / 450 \mathrm{~nm}=0.266 \mathrm{~J} /$ mole

Watt $=\mathrm{J} /$ second, then $\mathrm{W} / \mathrm{m}^{2}=\mathrm{J} / \mathrm{s} / \mathrm{m}^{2}$

If solar energy was $0.317 \mathrm{~W} / \mathrm{m}^{2}$ at $450 \mathrm{~nm}$ :

$\left(0.317 \mathrm{~W} \mathrm{~m}^{-2}\right) /(0.266 \mathrm{~J} / \mu$ mole photons $/ \mathrm{nm})=1.192 \mu$ moles $/ \mathrm{s} / \mathrm{m}^{2}$

Therefore: There were $1.192 \mu$ moles of photons striking a square meter of earth's surface every second at wavelength $450 \mathrm{~nm}$. 


\section{Canopy Temperature, Soil Temperature, Air Temperature.}

Turf canopy temperatures, soil temperature, and air temperature were measured at 2:00 P.M around the $20^{\text {th }}$ day of each month depending upon weather conditions. An infrared temperature thermometer (Standard Oil Engineered Materials Co., Solon, OH) was used to assess turf canopy temperature on calm days under clear skies. A bimetal analogue thermometer (Rio Temp. San Diego, CA) was used to measure soil temperature at the same time turf canopy temperatures were recorded. Measurements were observed at a soil depth of $15 \mathrm{~cm}$. Plot temperature measurements were sampled three times and the mean recorded. Air temperature was recorded as an average between the air temperature at the beginning and at the end of the period required to measure turf canopy temperatures at each site.

$\underline{\text { Soil Moisture. }}$

Soil moisture was determined monthly at 4:00 P.M. by time domain reflectometry (TDR; Mesa Systems Co., Framingham, MA). The use of TDR provides a nondestructive and accurate measurement for soil moisture content. Two TDR probes were inserted into the soil and moisture content was measured at a depth of $16 \mathrm{~cm}$. Measurements were made three times for each plot in each month and an average recorded for analysis. 
Color, Density, and Disease Assessment.

Each plot was visually rated for turf color, density, and disease assessment

monthly. Color was rated on a scale from 1 through $9(1=$ brown, $5=$ yellow-green, and $9=$ blue-green). Density was visually rated as a percentage of potential density. The disease incidence was rated on a scale of 1 through $5(0=$ no disease, $5=$ plots completely infected).

$\underline{\text { Root Mass and Carbohydrates Analysis. }}$

Three soil plugs were collected from each plot using a $2.54 \mathrm{~cm}$ diameter soil probe monthly to determine root mass. Root mass was evaluated at a depth of 0 to 15 $\mathrm{cm}$. Soil was washed from the roots with mild water through a $24 \mathrm{Mesh}$ screen and the samples were oven-dried at $55^{\circ} \mathrm{C}$ for 48 hours. Dry root mass was measured using a halance (Ohaus Corp., Florham Park, NJ), recorded in mg, then stored in a freezer for future total nonstructural carbohydrate (TNC) analysis. Carbohydrate concentrations were extracted using a modified Weinmann (1947) manner consistent with Smith (1981) except that a mixture of $\alpha$-amylase (Sigma No.2643, Sigma Chemical Co., St. Louis, MO) and amyloglucosidase (Sigma No.7420, Sigma Chemical Co., St. Louis, MO) was used in place of Mylase 100 enzyme (Bell and Danneberger, 1999). Root samples were ground in a Wiley Mill (Arthur H. Thomas Co. Philadelphia, PA), weighed to $30 \mathrm{mg}$, boiled for $5 \mathrm{~min}$ in double-distilled, demineralized water, and incubated in a mixture of $\alpha$-amylase and amyloglucosidase solution for $24 \mathrm{~h}$ at $45^{\circ} \mathrm{C}$ to degrade starch to glucose. Solutions were filtered through Whatman No.1 paper before fructosans were hydrolyzed in $0.5 \mathrm{M}$ sulfuric acid. High performance liquid chromatography (HPLC) was used to 
measure the glucose and fructose extracted from the root tissue. Sample extract was automatically injected using an automated sampler into a DX500 HPLC (Dionex Co., Sunnyvale, CA) unit equipped with the GP40 gradient pump, and ED40 electronic dectector. Total nonstructural carbohydrate (TNC) was calculated using area units developed by the PeakNet Chromatography Workstation (Dionex Co., Sunnyvale, CA). The formula for conversion of area units to $\mathrm{mg}$ (TNC) / $\mathrm{g}$ (root tissue) was:

- $30 \mathrm{mg}$ of sample was extracted and the extraction was brought to $30 \mathrm{ml}$.solusion.

- Standards $(2,4$, and $10 \mathrm{nmol}$ of glucose, fructose, and sucrose $)$ were prepared in $50 \mu \mathrm{l}$ of water.

- Molecular formula of both glucose and fructose is $\mathrm{C}_{6} \mathrm{H}_{12} \mathrm{O}_{6}$

1. nmol of TNC in root

$=($ Area unit of sample $/$ Area unit of standard $) \times 30 \mathrm{ml}$ (extract $) \times 1000(\mu \mathrm{l} / \mathrm{ml})$ $\mathrm{nmol}$ of standard/ injection $(50 \mu \mathrm{l})$

2. $\mu \mathrm{mol}$ of TNC/g of root

$=$ nmol of TNC in root tussue $/ 1000(\mathrm{nmole} / \mu \mathrm{mol})$ $30 \mathrm{mg}$ (root tissue) $\times 1000(\mathrm{mg} / \mathrm{g})$

3. $\mathrm{mg}$ of TNC/g of root tissue

$=\mu \mathrm{mol}$ of TNC g of root $\times 180(\mathrm{~mol} / \mathrm{g}$; in glucose or fructose $) \times 1000(\mathrm{mg} / \mathrm{g})$ $1000000(\mu \mathrm{mol} / \mathrm{mol})$

4. mg of TNC in enzyme blank is subtracted from TNC amount in sample for actual amount of TNC in sample.

Statistical Analysis.

A treatment data for both 2000 and 2001 were analyzed by analysis of variance (ANOVA) for a completely randomized design using the Statistical Analysis System (SAS Institute, Cary, NC) and mean separations were determined by Fisher's protected 
least significant difference (LSD) at $P \leq 0.05$. Overall observations were also analyzed using ANOVA when treatment by rating date interaction was not significant.

\section{Results and Discussion}

Simulated artificial shade structures covered with $80 \%$ light reduction cloth received an average of $40.3 \%$ photosynthetically active radiation (PAR) available in full sun measured monthly for two growing seasons while overall PAR in airflow restriction plots was not significantly different from that in full sun. The overall air speed in airflow restriction structures covered on four sides with cloth material to limit air movement was $0.3 \mathrm{~m} \mathrm{~s}^{-1}$ while shade structures did not affect airflow across the plots compared with control and averaged $4.5 \mathrm{~m} \mathrm{~s}^{-1}$.

Turf canopy temperature in full sun and in airflow restriction plots were consistently higher than in shade for both growing seasons in both cultivars (Table 1a and lb). Turf canopy temperature in full sun and airflow restriction plots measured as high as $37^{\circ} \mathrm{C}$ during the summer 2000 (Table 1a and $\mathrm{lb}$ ). Soil temperatures in shade were also consistently lower than in full sun and air restriction plots. Therefore, it can be concluded that turf in shade had less heat stress than turf in full sun and airflow restriction plots even though less PAR was available to synthesize carbohydrates through photosynthesis. High air and soil temperatures may severely decrease turt quality, root

growth, and photosynthetic activity in creeping bentgrass (Xu and Huang, 2000a). High soil temperature is detrimental to root growth and development which may affect shoot growth. Xu and Huang (2000a) concluded that soil temperature was more detrimental 
than air temperature to plant growth and lower soil temperature promoted shoot and root growth even when air temperature was supraoptimal. The researchers also found that total nonstructural carbohydrates in both roots and shoots decreased with increasing soil and air temperatures (Xu and Huang, 2000b).

For the first two months of 2000 , turf in shade plots maintained a darker green color than turf in full sun and airflow restricted plots for 'SR1020' creeping bentgrass (Table 2a). In full sun, the 'SR 1020' turf was darker than in airflow restriction in July and October 2000, and from July to October 2001 (Table 2a). Compared to shaded turf, turf color was negatively affected by airflow restriction due to disease and algae growth for 'SR1020' creeping bentgrass (Table 2a) during both years. Turf in airflow restriction maintained darker color than in shade in September and October 2001. Shade and airflow restriction caused lighter color than full sun in September and October 2000, and June, September, and October 2001 (Table 2b). The microenvironment in airflow restriction plots may be more favorable for the occurrence of disease growth due to lower transpiration rates, greater heat stress, and greater length of canopy wetness. Terrestrial algae were often observed where disease such as dollar spot and brown patch caused turf damage. In airflow restriction plots, this was especially true for 'SR1020' creeping bentgrass in summer of 2000 and 2001 (Table 3a). Turf in shade started to decline in July 2000, and remained less dense than turf in control plots for 'SR1020' creeping bentgrass. However, turf in shade had greater density in April and May 2000, and in August, September, and October 2001 than in airflow restriction for the 'L93' cultivar (Table 3a). Monthly visual ratings for density in control turf plots were significantly higher than in shade and air restriction during most of the second year in 'SR1020' creeping bentgrass 
(Table 3a). Turf in full sun had higher density than in shade in June, September, October 2000, and from July to October 2001 for 'L93' creeping bentgrass (Table 3b). Compared to airflow restriction plots, shaded plots maintained lower turf density in October 2000 , and 2001 for 'L93' creeping bentgrass (Table 3b). Higher turf density implies that more turf canopy was available for the interception of PAR to produce carbohydrates. During the second year, brown patch was present in air restriction plots in August for both cultivars (Table 4a and 4b). Control plots showed no difference compared to airflow restriction plots except July 2001 for 'SR 1020 ' creeping bentgrass. Less disease occurred in shaded plots than in airflow restricted and control plots in 'SR1020'; however, no or low disease damage was observed in 'L93' during two growing season (Table 4b).

There was no significant difference in soil moisture content among treatments except in June 2001 in 'SR1020' creeping bentgrass. However, the overall soil moisture in airflow restriction plots was higher than in shade and control in 'SR1020' (Table 5). It was hypothesized that turf in full sun, which had more rootmass and a deeper root system than in shade and airflow restriction, could use more soil moisture to survive summer heat stress through transpiration than turf in light reduction or airflow restricted plots. However, it is possible that wind across the shaded plots increased transpiration by reducing boundary layer resistance. Sunlight in the airflow restriction plots may have promoted evaporation, but the energy produced by sunlight could not overcome the higher boundary layer resistance compared with shaded and controlled turf. High water infiltration rate, thinner thatch layer, and lower organic contents in the 'L93'sand may have eliminated the difference among the treatments. 
Root mass was constantly less in shade than in full sun from July to October 2000 and from May to October 2001 for 'SR1020' creeping bentgrass and was significantly lower in shade than the control except for April 2000, and every month for 2001 in 'L93' creeping bentgrass (Table 6). In contrast to shade, turf in airflow restriction plots had greater rootmass in May and June 2000, and May and June 2001 for 'L93' creeping bentgrass. In the first year, the fructose levels of all turf declined severely in summer due to environmental stresses and treatment effects (Table 7a). In September and October 2000 , turf in the control plots contained more root carbohydrates than in shade for both cultivars (Table 7a). Bell and Danneberger (1999) found no significant difference in whole plant TNC content when comparing turf in full sun to perpetual shade, and temporal shade even though perpetual shade had the highest TNC content and full sun the lowest.

The results obtained for two growing seasons indicated that shade caused lower canopy and soil temperature, lighter color, lower density, significantly less disease, less root mass, and lower carbohydrates after the $1^{\text {st }}$ summer when compared to full sun. Airflow restriction resulted constantly higher canopy and soil temperature, lighter color, lower density, higher overall disease occurrence, less root mass, and lower carbohydrates after the $1^{\text {st }}$ summer than full sun. Compared to turf in shade, turf under airflow restriction was exposed to higher canopy and soil temperature, was more susceptible to disease, had greater root mass, and consistently more carbohydrates in 'L93' creeping bentgrass during and after summer 2000 . Airflow restriction was more detrimental to turf growth and development in terms of greater disease incidence, lower turf density, and 
poorer color than shade. Shade, however, caused lower root mass and root carbohydrates than air restriction. 


\section{References}

Beard, J.B. 1973. Turfgrass: Science and Culture. Prentice Hall, Inc., Englewood Cliffs, NJ. p. 181-208 and 313-324.

Bell, G.E., and T.K. Danneberger. 1999. Temporal shade on creeping bentgrass turf. Crop Sci. 39:1142-1146.

Burton, G.W., J.E. Jackson, and F.E. Knox. 1959. The influence of light reduction upon the production, persistence, and chemical composition of Coastal bermudagrass, Cynodon dactylon. Agron. J. 51:537-542.

Dudeck, A.E., and C.H. Peacock. 1992. Shade and turfgrass culture. In D.V. Waddington et al. (ed). Turfgrass. ASA Monogr. 32. ASA, CSSA, and SSSA. Madison, WI.

Duff, D.T., and J.B. Beard. 1966. Effects of air movement and syringing on the microclimate of bentgrass turf. Agron. J. 58:495-497.

Eriksen, F.I., and A.S. Whitney. 1981. Effects of light intensity on growth of some tropical forage species. I. Interaction of light intensity and nitrogen fertilization on six forage grasses. Agron. J. 73:427-433.

Grace, J, and G. Russell. 1977. The effect of wind on grasses. III. Influence of continuous drought or wind on anatomy and water relations in Festuca arundinacea Schreb. J. Exp. Bot. 28:268-278.

Inosaka, M.O., K. Ito, H. Numaguchi, and M. Misumi. 1977. Studies on the productivity of some tropical grasses. 4. Effect of shading on heading habit of some tropical grasses. Jpn. J. Trop. Agric. 20:2365-2390.

Kitano and Iguchi. 1992. Dynamics of whole-plant water balance and leaf growth in response to evaporative demand. II. Effect of change in wind velocity. Biotronics 21:51-60.

Nobel P.S. 1991. Wind-Heat conduction and convection. p. 361-374. in Physicochemical and Environmental Plant Physiology. Academic Press, Inc. San Diego.

Qian, Y.L., and M.C. Engelke. 1999. Influence of trinexapac-ethyl on 'Diamond' zoysiagrass in a shade environment. Crop Sci.39:202-208.

Rood, S.B., F.D. Beall, and R.P. Pharis. 1986. Photocontrol of gibberellin metabolism in situ in maize. Plant Physiol. 80: 448-453. 
Russell, G., and J. Grace. 1978. The effect of wind on grasses. V. Leaf extension, diffusive conductance, and photosynthesis in the wind tunnel. J. Exp. Bot. 29:245255 .

Russell, G., and J. Grace. 1979. The effect of wind speed on the growth of grasses. J. Appl. Ecol. 16:507-514.

Smith, D. 1981. Removing and analyzing total nonstructural carbohydrates from plant tissue. Wisconsin Agric. Exp. Stn. Res. Rep. 2107.

Vargas, J.M., and J.B. Beard. 1981. Shade environment-disease relationships of Kentucky bluegrass cultivars. p. 391-395. In R.W. Sheard (ed.) Proceedings of the Fourth International Turfgrass Research Conference., Guelph, Ontario, Canada.

Weinmann, H. 1947. Determination of total availbble carbohydrates in plants. Plant Physiol. 22:279-289.

Xu, Q., and B. Huang. 2000a. Growth and physiological responses of creeping bentgrass to changes in air and soil temperature. Crop Sci. 40:1363-1368.

Xu, Q., and B. Huang. 2000b. Effects of differential air and soil temperature on carbohydrate metabolism in creeping bentgrass. Crop Sci. 40:1368-1374. 
Table 1a. Turf canopy, soil, and air temperatures $\uparrow$ for creeping bentgrass (Agrostis palustris Huds.) cultivar, 'SR1020'. Means are based on three subsamples from three replications of each treatment.

\begin{tabular}{|c|c|c|c|c|c|c|c|c|c|c|c|c|c|c|}
\hline \multirow[b]{2}{*}{ Treatments } & \multicolumn{7}{|c|}{2000} & \multicolumn{6}{|c|}{2001} & Overall \\
\hline & $4 / 20$ & $5 / 20$ & $6 / 19$ & $7 / 21$ & $8 / 23$ & $9 / 21$ & $10 / 23$ & $5 / 21$ & $6 / 22$ & $7 / 23$ & $8 / 22$ & $9 / 21$ & $10 / 18$ & \\
\hline
\end{tabular}

Turf Canopy Temperature*

\begin{tabular}{|c|c|c|c|c|c|c|c|c|c|c|c|c|c|c|}
\hline Air Block & 31.3 & 34.3 & 35.7 & 35.3 & 36.3 & 37.7 & 25.0 & 30.3 & 32.3 & 34.7 & 32.7 & 27.3 & 21.7 & 31.9 \\
\hline Shade & 22.0 & 25.3 & 31.0 & 31.0 & 30.0 & 30.3 & 21.0 & 22.7 & 27.7 & 28.7 & 27.7 & 23.7 & 16.3 & 25.9 \\
\hline Control & 30.0 & 33.7 & 34.3 & 34.0 & 35.0 & 37.3 & 25.7 & 29.3 & 31.3 & 32.7 & 31.0 & 26.3 & 20.3 & 30.8 \\
\hline LSD & 0.9 & 1.2 & 0.9 & 0.8 & 0.8 & 0.8 & 0.8 & 0.8 & 1.5 & 1.6 & 2.0 & 1.2 & 1.5 & 1.0 \\
\hline
\end{tabular}

Soil Temperature**

\begin{tabular}{lrrrrrrrrrrrrrr}
\hline Air Block & 22.0 & 23.3 & 25.0 & 21.0 & 19.3 & 21.7 & 12.0 & 20.7 & 22.7 & 23.0 & 20.7 & 17.3 & 12.3 & 19.9 \\
Shade & 16.7 & 19.0 & 20.7 & 18.3 & 17.3 & 18.3 & 9.3 & 16.7 & 18.7 & 18.3 & 16.7 & 14.3 & 8.7 & 16.4 \\
Control & 19.7 & 22.7 & 25.0 & 21.0 & 19.7 & 21.0 & 11.7 & 20.3 & 22.3 & 22.3 & 20.3 & 16.7 & 11.7 & 19.5 \\
LSD & 1.5 & 1.3 & 0.8 & 1.2 & 1.5 & 0.9 & 0.9 & 1.5 & 1.2 & 1.2 & 1.2 & 0.9 & 1.2 \\
\hline
\end{tabular}

Air Temperature***

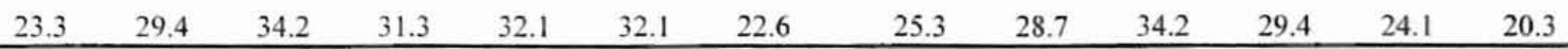

$\uparrow$ Temperatures were recorded as a degree of Celsius $\left({ }^{\circ} \mathrm{C}\right)$.

* Significant at Fisher's protected least significant different ( $P \geq 0.05)$.

* Measured with infrared thermometer on calm days under clear skies.

** Measured with bimetal thermometer at $15 \mathrm{~cm}$ below the surface.

*** Measured with weather station at OSU turf center. 
Table lb. Turf canopy, soil, and air temperatures † for creeping bentgrass (Agrostis palustris Huds.) cultivar, 'L93'. Means are based on three subsamples from three replications of each treatment.

\begin{tabular}{|c|c|c|c|c|c|c|c|c|c|c|c|c|c|c|}
\hline \multirow[b]{2}{*}{ Treatments } & \multicolumn{7}{|c|}{2000} & \multicolumn{6}{|c|}{2001} & \multirow[t]{2}{*}{ Overall } \\
\hline & $4 / 20$ & $5 / 20$ & $6 / 19$ & $7 / 21$ & $8 / 23$ & $9 / 21$ & $10 / 23$ & $5 / 21$ & $6 / 22$ & $7 / 23$ & $8 / 22$ & $9 / 21$ & $10 / 18$ & \\
\hline & \multicolumn{14}{|c|}{ Turf Canopy Temperature* } \\
\hline Air Block & 31.3 & 34.0 & 36.0 & 35.3 & 36.0 & 35.7 & 26.0 & 30.7 & 32.0 & 34.3 & 33.3 & 27.7 & 22.0 & 31.9 \\
\hline Shade & 22.7 & 25.3 & 31.0 & 31.3 & 30.0 & 28.3 & 21.0 & 22.3 & 28.3 & 29.3 & 27.7 & 24.0 & 16.7 & 26.0 \\
\hline Control & 30.3 & 33.0 & 34.7 & 35.0 & 34.3 & 35.7 & 25.7 & 29.7 & 31.7 & 33.0 & 31.7 & 27.3 & 20.7 & 30.0 \\
\hline $\operatorname{LSD}_{t}^{*}$ & 1.2 & 1.5 & 0.8 & 1.2 & 0.8 & 1.2 & 0.8 & 0.8 & 0.9 & 0.8 & 1.5 & 0.9 & 1.2 & 0.5 \\
\hline
\end{tabular}

Soil Temperature**

\begin{tabular}{lcccccccccccccc}
\hline Air Block & 22.0 & 23.3 & 25.0 & 21.3 & 20.0 & 21.3 & 11.3 & 21.0 & 22.3 & 23.3 & 20.7 & 17.7 & 12.0 & 20.1 \\
Shade & 19.0 & 19.7 & 21.7 & 18.3 & 18.0 & 18.0 & 9.0 & 17.0 & 18.7 & 18.3 & 17.7 & 15.3 & 9.3 & 16.9 \\
Control & 22.7 & 23.0 & 25.0 & 21.0 & 20.3 & 20.7 & 11.3 & 20.7 & 21.7 & 21.7 & 20.3 & 17.0 & 11.3 & 20.1 \\
LSD+ & 1.5 & 0.9 & 0.8 & 1.2 & 1.5 & 0.9 & 1.2 & 0.8 & 1.2 & 1.2 & 1.2 & 0.9 & 0.8 & 0.3 \\
\hline
\end{tabular}

\section{Air Temperature***}

$\dagger$ Temperatures were recorded as a degree of Celsius $\left({ }^{\circ} \mathrm{C}\right)$.

* Significant at Fisher's protected least significant different $(P \geq 0.05)$.

* Measured with infrared thermometer on calm days under clear skies.

** Measured with bimetal thermometer at $15 \mathrm{~cm}$ below the surface.

*** Measured with weather station at OSU turf center. 
Table 2a. Turf color ratings $\dagger$ for creeping bentgrass (Agrostis palustris Huds.), 'SR1020'. Means are based on three subsamples from three replications of each treatment.

\begin{tabular}{|c|c|c|c|c|c|c|c|c|c|c|c|c|c|}
\hline \multirow[b]{2}{*}{ Treatments } & \multicolumn{7}{|c|}{2000} & \multicolumn{6}{|c|}{2001} \\
\hline & $4 / 20$ & $5 / 20$ & $6 / 19$ & $7 / 21$ & $8 / 23$ & $9 / 21$ & $10 / 23$ & $5 / 21$ & $6 / 22$ & $7 / 23$ & $8 / 22$ & $9 / 21$ & $10 / 18$ \\
\hline Air Block & 7.0 & 7.0 & 6.3 & 6.0 & 6.3 & 5.3 & 6.7 & 6.7 & 7.0 & 6.0 & 4.3 & 4.3 & 5.3 \\
\hline Shade & 9.0 & 9.0 & 7.0 & 6.3 & 6.0 & 5.7 & 7.0 & 7.0 & 7.6 & 6.7 & 6.0 & 5.7 & 7.0 \\
\hline Control & 7.7 & 7.0 & 8.0 & 7.0 & 6.7 & 6.7 & 8.7 & 7.0 & 7.3 & 7.0 & 6.7 & 6.3 & 6.7 \\
\hline $\mathrm{LSD} \dagger$ & 0.6 & 0 & 0.7 & 0.6 & NS & 1.2 & 0.9 & NS & NS & 0.8 & 1.3 & 1.5 & 0.9 \\
\hline
\end{tabular}

+ Color was visually rated on a scale of 1 through $9(1=$ brown, $5=$ yellow-green, $9=$ dark green $)$.

* Significant at Fisher's protected least significant different $(P \geq 0.05)$. 
Table 2b. Turf color ratings $\uparrow$ for creeping bentgrass (Agrostis palustris Huds.) cultivar 'L93'. Means are based on three subsamples from three replications of each treatment.

\begin{tabular}{|c|c|c|c|c|c|c|c|c|c|c|c|c|c|}
\hline \multirow[b]{2}{*}{ Treatments } & \multicolumn{7}{|c|}{2000} & \multicolumn{6}{|c|}{2001} \\
\hline & $4 / 20$ & $5 / 20$ & $6 / 19$ & $7 / 21$ & $8 / 23$ & $9 / 21$ & $10 / 23$ & $5 / 21$ & $6 / 22$ & $7 / 23$ & $8 / 22$ & $9 / 21$ & $10 / 18$ \\
\hline Air Block & 9.0 & 8.3 & 8.3 & 8.0 & 7.7 & 7.0 & 8.0 & 8.0 & 8.0 & 7.3 & 6.3 & 6.7 & 8.0 \\
\hline Shade & 9.0 & 9.0 & 8.3 & 8.0 & 7.3 & 7.0 & 7.7 & 8.0 & 8.0 & 7.3 & 6.3 & 5.3 & 6.3 \\
\hline Control & 9.0 & 9.0 & 9.0 & 8.7 & 8.7 & 8.7 & 9.0 & 8.0 & 9.0 & 8.3 & 7.3 & 8.7 & 9.0 \\
\hline $\mathrm{LSD}_{\dagger}^{+}$ & NS & 0.6 & NS & NS & 1.2 & 1.3 & 0.7 & NS & 0 & NS & NS & 1.5 & 0.7 \\
\hline
\end{tabular}

Color was visually rated on a scale of 1 through $9(1=$ brown, $5=$ yellow-green, $9=$ dark green $)$.

$\$$ Significant at Fisher's protected least significant different $(P \geq 0.05)$. 
Table 3a. Turf density ratings $†$ for creeping bentgrass (Agrostis palustris Huds.) cultivar, 'SR1020'. Means are based on three subsamples from three replications of each treatment.

\begin{tabular}{|c|c|c|c|c|c|c|c|c|c|c|c|c|c|c|}
\hline \multirow[b]{2}{*}{ Treatments } & \multicolumn{7}{|c|}{2000} & \multicolumn{6}{|c|}{2001} & \multirow[t]{2}{*}{ Overal } \\
\hline & $4 / 20$ & $5 / 20$ & $6 / 19$ & $7 / 21$ & $8 / 23$ & $9 / 21$ & $10 / 23$ & $5 / 21$ & $6 / 22$ & $7 / 23$ & $8 / 22$ & $9 / 21$ & $10 / 18$ & \\
\hline Air Block & 94.0 & 87.3 & 81.3 & 76.3 & 71.7 & 68.7 & 81.7 & 85.7 & 84.3 & 79.3 & 53.3 & 60.0 & 62.0 & 75.8 \\
\hline Shade & 97.7 & 95.0 & 86.3 & 70.7 & 69.0 & 69.0 & 78.3 & 84.3 & 85.7 & 78.3 & 71.7 & 74.3 & 84.3 & 80.4 \\
\hline Control & 93.0 & 89.7 & 84.0 & 93.0 & 92.0 & 95.0 & 97.0 & 88.0 & 94.0 & 90.7 & 91.3 & 89.7 & 86.7 & 91.1 \\
\hline LSD* & 3.1 & 4.1 & 2.7 & 6.4 & 3.9 & 3.9 & 4.7 & 3.5 & 3.7 & 7.2 & 15.1 & 10.8 & 7.0 & 4.1 \\
\hline
\end{tabular}

$\dagger$ Visual ratings for percentage of potential density ( $\%)$.

† Significant at Fisher's protected least significant different $(P \geq 0.05)$. 
Table 3b. Turf density rating $\uparrow$ for creeping bentgrass (Agrostis palustris Huds.) cultivar, 'L93'. Means are based on three subsamples from three replications of each treatment.

\begin{tabular}{|c|c|c|c|c|c|c|c|c|c|c|c|c|c|}
\hline \multirow[b]{2}{*}{ Treatments } & \multicolumn{7}{|c|}{2000} & \multicolumn{6}{|c|}{2001} \\
\hline & $4 / 20$ & $5 / 20$ & $6 / 19$ & $7 / 21$ & $8 / 23$ & $9 / 21$ & $10 / 23$ & $5 / 21$ & $6 / 22$ & $7 / 23$ & $8 / 22$ & $9 / 21$ & $10 / 18$ \\
\hline Air Block & 99.0 & 99.0 & 91.6 & 88.3 & 83.3 & 76.7 & 78.3 & 93.3 & 93.7 & 86.7 & 72.7 & 77.3 & 89.0 \\
\hline Shade & 99.0 & 99.0 & 90.0 & 85.0 & 78.8 & 73.3 & 71.7 & 93.3 & 93.7 & 83.3 & 75.3 & 72.3 & 68.0 \\
\hline Control & 99.0 & 99.0 & 95.0 & 95.0 & 83.3 & 88.3 & 93.3 & 95.0 & 93.7 & 94.3 & 89.0 & 91.7 & 95.7 \\
\hline LSD & NS & NS & 3.3 & NS & NS & 8.2 & 5.8 & NS & NS & 8.9 & 9.3 & 7.6 & 4.2 \\
\hline
\end{tabular}

$\uparrow$ Visual rating for percentage of potential density ( $\%)$.

* Significant at Fisher's protected least significant different $(P \geq 0.05)$. 
Table 4a. Dollar spot (Sclerotinia homoeocarpa F.T. Bennett) and brown patch (Rhizoctonia solani Kuhn.) assessments $\dagger$ for creeping bentgrass (Agrostis palustris Huds.) cultivar, 'SR1020'. Means were calculated from three replications of each treatment each month.

\begin{tabular}{|c|c|c|c|c|c|c|c|c|c|c|c|c|c|c|}
\hline \multirow[b]{2}{*}{ Treatments } & \multicolumn{7}{|c|}{2000} & \multicolumn{6}{|c|}{2001} & \multirow[t]{2}{*}{ Overall } \\
\hline & $4 / 20$ & $5 / 20$ & $6 / 19$ & $7 / 21$ & $8 / 23$ & $9 / 21$ & $10 / 23$ & $5 / 21$ & $6 / 22$ & $7 / 23$ & $8 / 22$ & $9 / 21$ & $10 / 18$ & \\
\hline & \multicolumn{14}{|c|}{ Dollar Spot } \\
\hline Air Block & - & 2.0 & 2.3 & 2.0 & 2.0 & 2.3 & 1.7 & 2.0 & 1.0 & 2.7 & 3.3 & 2.3 & 2.3 & 2.1 \\
\hline Shade & - & 0 & 1.0 & 0.7 & 0.3 & 0.7 & 0 & 0.3 & 0 & 1.0 & 1.3 & 1.0 & 1.0 & 0.6 \\
\hline Control & - & 1.0 & 2.0 & 1.3 & 1.7 & 2.0 & 1.0 & 2.3 & 1.0 & 1.7 & 2.7 & 2.0 & 2.3 & 1.8 \\
\hline $\mathrm{LSD}_{ \pm}^{+}$ & - & 0 & 0.7 & 0.9 & 1.5 & 0.9 & 0.7 & 0.9 & 0 & 0.9 & 1.6 & 0.7 & 0.9 & 0.2 \\
\hline
\end{tabular}

Brown Patch

\begin{tabular}{lrrrrrrrrrrrrrrr}
\hline Air Block & - & 0 & 2.7 & 2.7 & 0 & 0 & 0 & 0 & 0 & 0 & 2.3 & 1.7 & 0 & 0.8 \\
Shade & - & 0 & 0 & 0 & 0 & 0 & 0 & 0 & 0 & 0 & 0 & 0 & 0 & 0 \\
Control & - & 0 & 0 & 0 & 0 & 0 & 0 & 0 & 0 & 0 & 0 & 0 & 0 & 0 \\
LSD & - & NS & 0.7 & 0.7 & NS & NS & NS & NS & NS & NS & NS & NS & NS & NS \\
\hline
\end{tabular}

Disease assessments were visually rated from 0 to $5(0=$ no disease, $5=$ complete infection).

$\mp$ Significant at Fisher's protected least significant different $(P \geq 0.05$ ). 
Table 4b. Dollar spot (Sclerotinia homoeocarpa F.T. Bennett) and brown patch (Rhizoctonia solani Kuhn.) assessments † for creeping bentgrass (Agrostis palustris Huds.) cultivar, 'L93'. Means were calculated from three replications of each treatment each month.

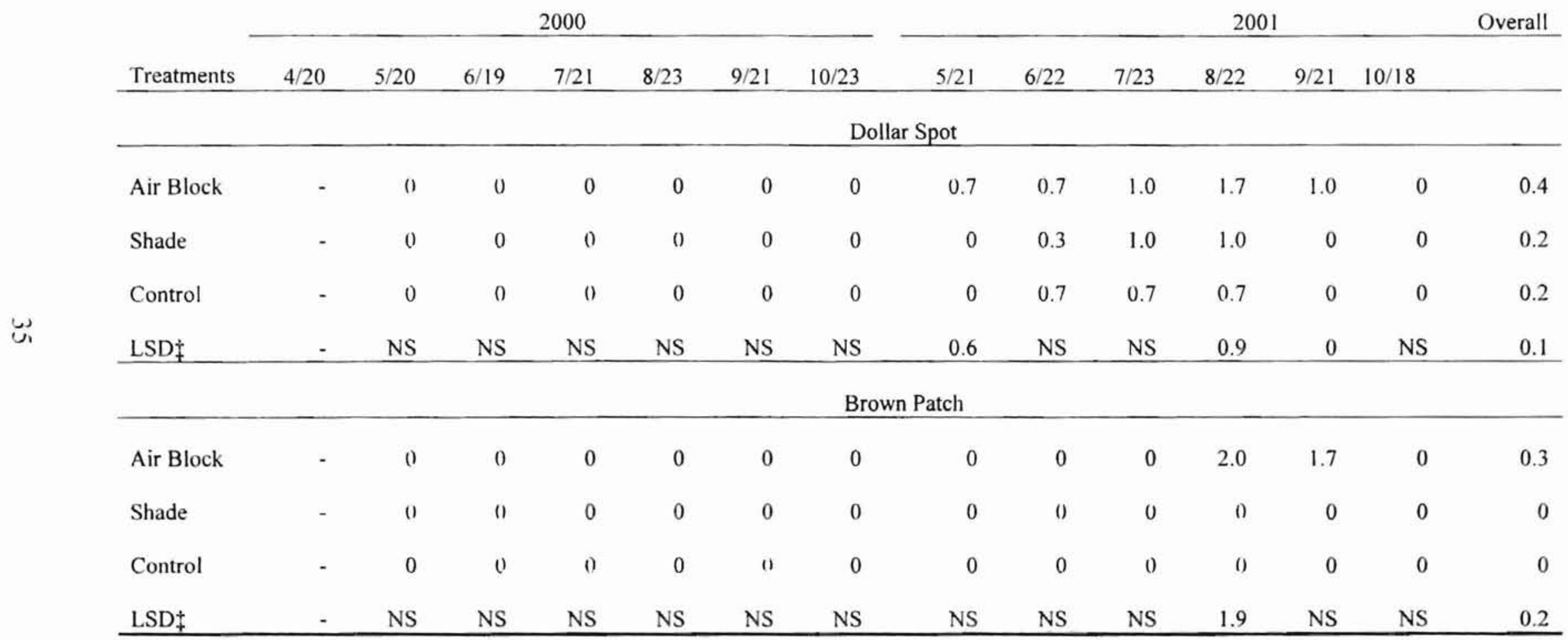

$\dagger$ Disease assessments were visually rated from 0 to $5(0=$ no disease, $5=$ complete infection).

$\ddagger$ Significant at Fisher's protected least significant different $(P \geq 0.05)$. 
Table 5. Relative soil moisture content $\dagger$ for creeping bentgrass (Agrostis palustris Huds.) cultivars, 'SR 1020' and 'L 93'. Means are based on three subsamples from three replications of each treatment.

\begin{tabular}{|c|c|c|c|c|c|c|c|c|c|c|c|c|c|c|}
\hline \multirow[b]{2}{*}{ Treatment } & \multicolumn{7}{|c|}{2000} & \multicolumn{6}{|c|}{2001} & \multirow[t]{2}{*}{ Overall } \\
\hline & $4 / 20$ & $5 / 20$ & $6 / 19$ & $7 / 21$ & $8 / 23$ & $9 / 21$ & $10 / 23$ & $5 / 21$ & $6 / 22$ & $7 / 23$ & $8 / 22$ & $9 / 21$ & $10 / 18$ & \\
\hline & \multicolumn{14}{|c|}{ SR 1020} \\
\hline Air Block & 18.0 & 15.3 & 15.7 & 14.5 & 15.0 & 15.2 & 16.6 & 16.6 & 16.0 & 14.3 & 14.5 & 14.8 & 17.0 & 15.6 \\
\hline Shade & 15.3 & 12.8 & 13.6 & 12.2 & 13.5 & 13.5 & 13.7 & 14.1 & 13.8 & 13.1 & 14.3 & 14.0 & 14.5 & 13,7 \\
\hline Control & 14.9 & 13.9 & 15.1 & 13.5 & 14.5 & 13.8 & 13.9 & 15.0 & 14.4 & 13.3 & 14.2 & 13.6 & 14.6 & 14.2 \\
\hline $\mathrm{LSD} \div$ & NS & NS & NS & NS & NS & NS & NS & NS & 1.8 & NS & NS & NS & NS & 0.54 \\
\hline & \multicolumn{14}{|c|}{ L 93} \\
\hline Air Block & 18.1 & 16.5 & 16.4 & 15.3 & 15.2 & 16.9 & 15.7 & 18.6 & 15.4 & 15.2 & 15.5 & 16.9 & 15.3 & 16.2 \\
\hline Shade & 17.9 & 16.1 & 15.5 & 15.5 & 15.3 & 15.9 & 15.3 & 16.0 & 15.4 & 15.8 & 15.9 & 15.6 & 15.7 & 15.8 \\
\hline Control & 16.8 & 16.5 & 16.2 & 15.5 & 15.5 & 15.2 & 16.1 & 19.4 & 16.5 & 15.7 & 15.5 & 15.5 & 15.8 & 16.2 \\
\hline LSD $\div$ & NS & NS & NS & NS & NS & NS & NS & NS & NS & NS & NS & NS & NS & NS \\
\hline
\end{tabular}

$\uparrow$ Soil moisture content ( $\%$ ) was measured at $15 \mathrm{~cm}$ below turf surface with time domain reflectometry (TDR ).

$\ddagger$ Significant at Fisher's protected least significant different $(P \geq 0.05)$. 
Table 6. Root mass † for creeping bentgrass (Agrostis palustris Huds.) cultivars, 'SR 1020' and 'L 93'. Means are based on three subsamples from three replications of each treatment.

2000

2001

$\begin{array}{lrrrrrrrrrrrrr}\text { Treatment } & 4 / 20 & 5 / 20 & 6 / 19 & 7 / 21 & 8 / 23 & 9 / 21 & 10 / 23 & 5 / 21 & 6 / 22 & 7 / 23 & 8 / 22 & 9 / 21 & 10 / 18\end{array}$

SR 1020

\begin{tabular}{|c|c|c|c|c|c|c|c|c|c|c|c|c|c|}
\hline Air Block & 138 & 128 & 139 & 115 & 33 & 34 & 45 & 94 & 55 & 20 & 17 & 21 & 23 \\
\hline Shade & 160 & 131 & 116 & 76 & 23 & 23 & 26 & 50 & 38 & 27 & 19 & 20 & 16 \\
\hline Control & 175 & 162 & 166 & 159 & 83 & 72 & 88 & 133 & 71 & 32 & 32 & 36 & 35 \\
\hline $\mathrm{LSD}_{+}^{+}$ & NS & NS & NS & 52 & 53 & 31 & 60 & 79 & 20 & NS & 8 & NS & 17 \\
\hline
\end{tabular}

\begin{tabular}{|c|c|c|c|c|c|c|c|c|c|c|c|c|c|}
\hline & & & & & & & L 93 & & & & & & \\
\hline Air Bloch & 172 & 190 & 155 & 84 & 27 & 30 & 67 & 127 & 62 & 28 & 19 & 14 & 21 \\
\hline Control & 191 & 203 & 215 & 144 & 70 & 94 & 140 & 163 & 85 & 49 & 37 & 30 & 40 \\
\hline $\mathrm{LSD}_{\ddagger}^{+}$ & NS & 46 & 30 & 49 & 26 & 20 & 50 & 44 & 12 & 15 & 9 & 7 & 12 \\
\hline
\end{tabular}

$\dagger$ Soil samples were collected with a soil probe $(2.54 \mathrm{~cm}$ in diameter $)$ at soil depth of $15 \mathrm{~cm}$ below the turf surface for measuring root mass $\left(\mathrm{mg} / 76 \mathrm{~cm}^{3}\right.$ of soil volume ).

$\dagger$ Significant at Fisher's protected least significant different ( $P \geq 0.05)$. 
Table 7. Total nonstructural cabohydrate (TNC) content $\dagger$ for creeping bentgrass (Agrostis palustris Huds.) cultivars, 'SR1020' and 'L93'. Means are based on three subsamples from three replications of each treatment.

\begin{tabular}{|c|c|c|c|c|c|c|c|c|c|c|c|c|c|c|c|c|c|c|c|c|c|}
\hline Treatments & \multicolumn{21}{|c|}{2000} \\
\hline & \multicolumn{21}{|c|}{ SR 1020} \\
\hline Air Block & 6.7 & 30.5 & 37.2 & 11.7 & 61.0 & 72.4 & 8.7 & 46.3 & 54.9 & 2.2 & 1.6 & 3.8 & 2.5 & 2.9 & 5.4 & 2.2 & 3.1 & 5.3 & 2.8 & 6.4 & 9.2 \\
\hline Control & 7.1 & 29.4 & 36.5 & 7.4 & 40.0 & 47.4 & 12.8 & 51.7 & 64.5 & 4.0 & 8.0 & 12.0 & 3.3 & 6.3 & 9.6 & 4.3 & 8.6 & 12.9 & 7.9 & 23.1 & 31.0 \\
\hline $\mathrm{LSD}_{\leftarrow}^{*}$ & NS & NS & NS & 3.0 & 17.9 & 20.6 & 4.8 & 17.5 & 22.1 & NS & 5.1 & 6.9 & NS & NS & NS & NS & 2.1 & 5.9 & 3.8 & 14.6 & 18.4 \\
\hline
\end{tabular}

\begin{tabular}{lrrrrrrrrrrrrrrrrrrrrrr} 
Air Block & 8.4 & 37.8 & 46.2 & 7.4 & 34.5 & 41.8 & 5.8 & 24.1 & 29.9 & 3.8 & 4.8 & 8.6 & 3.3 & 3.9 & 7.2 & 3.4 & 2.3 & 5.7 & 4.4 & 12.0 & 16.4 \\
Shade & 7.2 & 26.7 & 33.8 & 11.2 & 43.2 & 54.4 & 6.8 & 27.4 & 34.2 & 3.5 & 3.4 & 7.0 & 2.4 & 2.1 & 4.4 & 2.0 & 1.7 & 3.7 & 2.8 & 4.8 & 7.6 \\
Control & 13.4 & 42.5 & 55.8 & 9.7 & 53.2 & 62.8 & 12.8 & 53.7 & 66.4 & 5.1 & 9.6 & 14.6 & 4.2 & 5.9 & 10.1 & 4.4 & 7.7 & 12.0 & 6.3 & 15.4 & 21.7 \\
LSD* & 4.1 & NS & NS & NS & NS & NS & 2.4 & 9.9 & 11.4 & NS & 5.2 & 6.7 & 1.3 & NS & 5.1 & 1.2 & 1.6 & 2.7 & 0.9 & 4.8 & 5.5 \\
\hline
\end{tabular}

$\dagger$ Total nonstructural carbohydrate (TNC) contents ( $\mathrm{mg} / \mathrm{g}$ of root) were determined by High performance liquid chromatography (HPLC).

+ Significant at Fisher's protected least significant different $(P \geq 0.05)$.

* G: Glucose contents ( $\mathrm{mg} / \mathrm{g}$ of root).

** F: Fructose contents ( $\mathrm{mg} / \mathrm{g}$ of root). 


\title{
VITA
}

\author{
Kyungjoon Koh \\ Candidate for the Degree of \\ Master of Science
}

Thesis: SHADE AND AIRFLOW RESTRICTION EFFECTS ON CREEPING BENTGRASS GOLF GREENS

Major Field: Horticulture

Biographical:

Personal Data: Born in Seoul, S. Korea on January 7. 1971, the son of Heungchul Koh and Sookja Lee. Married Soyoun Park on December, 1997.

Education: Graduated from SeoCho High School, Seoul, S. Korea in 1990; Received Bachelor of Science degree in Crop and Soil Science, majoring in Turfgrass Management from North Carolina State University, Raleigh, North Carolina in May 1998. Completed the requirements for the Master of Science Degree with a major in Horticulture at Oklahoma State University in December, 2001.

Experience: Completed three turfgrass management internship at Crooked Creek Golf Club in Fuquay-Varina, NC during spring, summer, and fall, 1997. Employed by Crooked Creek Golf Club, Fuquay-Varina, $\mathrm{NC}$ as an Assistant Superintendent in 1998. Worked as a Graduate Research Assistant, Department of Horticulture and Landscape Architecture, Oklahoma State University, May 2000 to the present.

Professional Memberships: Golf Course Superintendent's Association of America, American Society of Agronomy, Crop Science Society of America. 